\title{
The discovery of placenta growth factor and its biological activity
}

\author{
Sandro De Falco ${ }^{1,2}$ \\ ${ }^{1}$ Angiogenesis Laboratory and Stem Cell Fate Laboratory \\ Institute of Genetics and Biophysics \\ 'Adriano Buzzati-Traverso' - CNR - Via Pietro Castellino \\ 111, 80131 Napoli, Italy \\ ${ }^{2}$ Correspondence: Tel, 39-081-6132354; \\ Fax, 39-081-6132706; E-mail, sandro.defalco @igb.cnr.it \\ http://dx.doi.org/10.3858/emm.2012.44.1.025 \\ Accepted 6 December 2011 \\ Available Online 9 January 2012
}

Abbreviations: BF-2, forkhead/winged helix transcription factor FoxD1; eNos, enodothelial nitric oxide synthase; HIFs, hypoxia inducible factors; HRE, hypoxia responsive element; MTF-1, metal transcription factor 1; NRP1 and NRP2, neuropilin 1 and 2; PIGF, placenta growth factor; TACE, TNF- $\alpha$ converting enzyme; TAM, tumor-associated macrophages; TIMP-3, tissue inhibitor of metalloproteinases; TK, tyrosine kinase; VEGFR-1 and VEGFR-2, VEGF receptor 1 and 2

\begin{abstract}
Angiogenesis is a complex biological phenomenon crucial for a correct embryonic development and for post-natal growth. In adult life, it is a tightly regulated process confined to the uterus and ovary during the different phases of the menstrual cycle and to the heart and skeletal muscles after prolonged and sustained physical exercise. Conversly, angiogenesis is one of the major pathological changes associated with several complex diseases like cancer, atherosclerosis, arthritis, diabetic retinopathy and age-related macular degeneration. Among the several molecular players involved in angiogenesis, some members of VEGF family, VEGF-A, VEGF-B and placenta growth factor (PIGF), and the related receptors VEGF receptor 1 (VEGFR-1, also known as FIt-1) and VEGF receptor 2 (VEGFR-2, also known as Flk-1 in mice and KDR in human) have a decisive role. In this review, we describe the discovery and molecular characteristics of PIGF, and discuss the biological role of this growth factor in physiological and pathological conditions.
\end{abstract}

Keywords: angiogenesis inducing agents; anoxia; endothelial cells; hypoxia; macrophages; neovascularization, pathologic; placenta growth factor; vascular endothelial growth factors

\section{PIGF gene and protein}

Placenta growth factor (PIGF) has been the second member of VEGF family discovered. The name refers to placenta since it was cloned from a human placental CDNA library (Maglione et al., 1991). The human plgf gene mapped to chromosome $14 q 24$, whereas mouse gene is located on chromosome 12qD. Both genes are formed by seven exons spanning $13.7 \mathrm{~kb}$ in human and $10.4 \mathrm{~kb}$ in mouse, excluding the upstream and downstream regulatory sequences (Maglione et al., 1993a; DiPalma et al., 1996).

Like the others members of VEGF family (Ferrara et al., 2003; Takahashi and Shibuya, 2005), different isoforms due to alternative splicing are encoded by human plgf gene. It encodes four isoforms, PIGF 1-4 (Maglione et al., 1993a; Cao et al., 1997; Yang et al., 2003), composed by 131, 152, 203 and 224 amino acids after the removal of signal peptide (18 amino acids residues in length), respectively.

The primary difference between the four isoforms is that PIGF-1 and PIGF-3 are non-heparin binding diffusible isoforms while PIGF-2 and PIGF-4 have additional (highly basic 21 amino acids) heparin binding domains (Hauser and Weich, 1993; Maglione et al., 1993a; Yang et al., 2003). Conversely, mouse plgf gene encodes for the single isoform PIGF-2, able to bind heparin and composed by 140 amino acids in its mature form (DiPalma et al., 1996).

PIGF is secreted as a glycosylated homodimer. The most well-known structural feature of PIGF is due to six cysteine residues of each monomer that are engaged to form three intra-chain disulfide bonds, generating a particular three-dimensional structure known as cystine-knot motif. Two other cysteine residues of each monomer are engaged to form two inter-chain disulfide bonds necessary for the formation of the homodimer. Each homodimer shows two cystine-knot motif located at the opposite poles of the molecule. Despite the human PIGF shows only $42 \%$ amino acid sequence identity with the most active member of VEGF family, the VEGF-A, its three-dimensional structure elucidated at $2.0 \AA$ resolution and compared with that of VEGF-A has evidenced a remarkable topological identity between the two proteins (Muller et al., 1997; lyer et al., 2001).

The PIGF-1 dimer consists of two $\alpha$-helices and 
seven $\beta$-strands per monomer, which are covalently linked by two inter-chain disulphide bonds in an anti-parallel fashion. Structural and mutagenesis analyses (Errico et al., 2004) indicated that two negatively charged residues located in the $\beta 3-\beta 4$ loop (Asp72 and Glu73) are critical for receptor binding. Other residues crucial for receptor recognition are located in the $\mathrm{N}$-terminal $\alpha$-helix as well as on the $\beta 6$ strand. The mutation of one (Asn84) of the two glycosylated residues of PIGF determines reduced binding activity indicating that, unlike in VEGF-A, glycosylation plays an important role in receptor binding.

The pro-angiogenic activity of VEGF family members is exerted through the binding and activation of two tyrosine kinase (TK) receptors, which were initially identified as receptors for VEGF-A: VEGFR-1 (de Vries et al., 1992) and VEGFR-2 (Terman et al., 1992). These receptors consist of seven extracellular Ig-like domains, a transmembrane domain and an intracellular TK domain. The binding of ligands induces receptor dimerization and phosphorylation. Despite the three-dimensional similarity with VEGF-A, PIGF has the property to bind exclusively VEGFR-1 receptor (Park et al., 1994), with high affinity compared to VEGF-A and to VEGF-B, the other members of the family able to specifically bind VEGFR-1 (Olofsson et al., 1998). The minimal receptor domain required for the binding of VEGF-A, VEGF-B and PIGF is the Ig-like domain two, as well documented by co-crystal threedimensional studies (Wiesmann et al., 1997; Christinger et al., 2004; lyer et al., 2010). It is relevant to highlight that for PIGF binding to VEGFR-1, the Ig-like domain 3 plays an important role. As for VEGF-A (Keyt et al., 1996), VEGFR-1 domains 2 and 3 are necessary and sufficient for the binding of PIGF with near-native affinity. However, whereas the deletion of domain 3 causes a 50-fold decrease in VEGF binding, the effect on PIGF is more consistent resulting in about 500 -fold reduction of binding of PIGF to the domain 2 (Davis-Smyth et al., 1998).

Despite the specificity of binding to VEGFR-1, PIGF may indirectly activate also VEGFR-2 in alternative ways. One possibility is represented by the ability of PIGF to bind VEGFR-1 displacing VEGF-A from this receptor and making VEGF-A available for the binding to VEGFR-2 (Carmeliet et al., 2001). Moreover, if coexpressed in the same cell, PIGF and VEGF-A may generate heterodimer form (DiSalvo et al., 1995) that is able to bind and activate VEGFR-1 but also to induce VEGFR1/VEGFR-2 dimerization, if both receptors are expressed on cell surface (Tarallo et al., 2010). In addition, it has been reported that once PIGF has activated VEGFR-1 receptor, VEGFR-2 may be activated by transphosphorylation mechanism (Autiero et al., 2003).

Furthermore, like other isoforms of VEGF family members able to bind heparin, PIGF-2 is able to bind the two coreceptors Neuropilin 1 and 2 (NRP1 and NRP2), discovered as coreceptors of class 3 semaphorins, via the recognition of their b1b2 domain (Migdal et al., 1998; Mamluk et al., 2002; Gaur et al., 2009). The interactions of PIGF isoforms and PIGF/VEGF-A heterodimer with receptors are summarized in Figure 1.

\section{PIGF expression}

PIGF is highly expressed in placenta throughout all stages of gestation. It has been proposed to control trophoblast growth and differentiation (Maglione et al., 1993a; Khaliq et al., 1996), thus suggesting a role for the protein during invasion of the trophoblast into the maternal decidua (Vuorela et al., 1997).

Immunohistochemistry analyses revealed the presence of PIGF in the vasculosyncytial membrane and in the media of large blood vessels of the

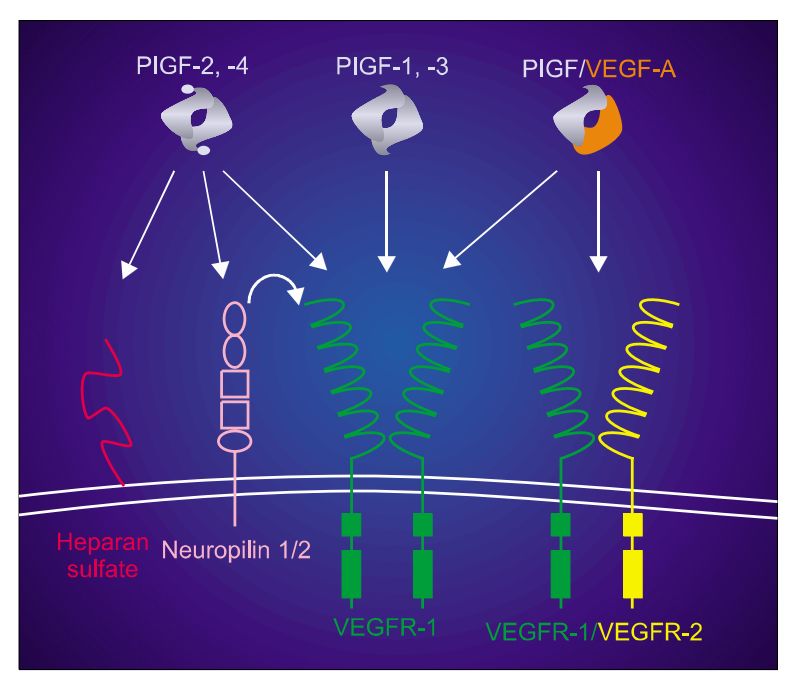

Figure 1. Schematic representation of binding properties of PIGF isoforms and PIGF/VEGF heterodimer. The possible dimers formed by PIGF monomer (gray) are represented. In the case of PIGF isoforms 2 and 4 , the heparin-binding domain is represented by additional filled oval. For the heterodimer, the VEGF moiety is in orange. For VEGF receptors (green VEGFR-1, yellow VEGFR-2) the seven Ig-like domains are represented as half ovals, whereas filled rectangles represent the intracellular TK domains. The extracellular Neuropilins receptor 1 and 2 domains are represented as vertical ovals (domains ai, a2), square $(\mathrm{b} 1, \mathrm{~b} 2)$ and an horizontal oval (domain c) (Mamluk et al., 2002). Heparan sulfate is represented in red. 
placenta. In situ hybridization analysis showed the presence of PIGF in the villous trophoblast while in this context VEGF-A is expressed in cells of mesenchymal origin within the chorionic plate, thus not in placenta cells (Khaliq et al., 1996; Vuorela et al., 1997).

PIGF is expressed during early embryonic development. Indeed, transcripts encoding mouse PIGF were abundant in trophoblastic giant cells associated with the parietal yolk sac at early stages of embryogenesis suggesting a role to coordinate vascularization in the deciduum and placenta during early embryogenesis (Achen et al., 1997). In addition PIGF is expressed at a low level in several other organs including the heart, lung, thyroid, skeletal muscle, and adipose tissue under normal physiological conditions (Viglietto et al., 1995; Persico et al., 1999; Voros et al., 2005).

At cellular level, the expression of PIGF was demonstrated in endothelial cells (Hauser and Weich, 1993; Yonekura et al., 1999), in thyroid cells (Viglietto et al., 1995), in immortalized or in transformed mouse embryonic fibroblasts and in NIH 3T3 cells (Carmeliet et al., 2001). Differently from VEGF-A, PIGF is expressed only in a limited number of tumor-derived cell lines (Persico et al., 1999; Cao, 2009).

Due to the main role that the hypoxic stimulus has in the upregulation of many pro-angiogenic factors when neo-vessels formation is required, studies to unveil the modulation of PIGF expression at molecular level have been executed mainly in hypoxic conditions. The main effectors of hypoxic stimulus are the transcriptional factors known as hypoxia inducible factors (HIFs) (Semenza, 1999). Although some reports indicated an upregulation of PIGF in cells exposed to hypoxia, the analysis of promoter/ enhancer region of PIGF did not show hypoxia responsive element (HRE) sequence, as observed for VEGF-A and VEGFR-1 receptor (Green et al., 2001; Oura et al., 2003; Selvaraj et al., 2003).

In this region, the presence of many putative recognition sequences for metal transcription factor 1 (MTF-1) and for NF-KB were observed. Indeed, the involvement of MTF-1 in immortalized/Rastransformed mouse embryonic fibroblast and in NIH 3T3 cells (Green et al., 2001), and the involvement of NF- $\kappa B$ in human embryonic kidney 293 cells (Cramer et al., 2005), has been demonstrated in the modulation of PIGF expression in hypoxic condition. However overexpression of HIF- $1 \alpha$ in endothelial cells (Yamakawa et al., 2003) or in primary cardiac and vascular cells (Kelly et al., 2003) positively influences the expression of PIGF. These results indicated that HIFs might have a role in the mechanism of control of PIGF expression. Therefore, further studies are needed to definitively clarify the molecular basis of hypoxia-induced PIGF expression. Moreover, PIGF expression was shown to be modulated by the forkhead/winged helix transcription factor FoxD1 (BF-2) in the developing kidney stroma due to a conserved HNF3b binding site identified on PIGF promoter region (Zhang et al., 2003).

Finally, PIGF expression is also controlled at a post-transcriptional level with a mechanism already described for other growth factors and for many oncogenes (Kozak, 1987; Parkin et al., 1988; Muller and Witte, 1989; Arrick et al., 1991). The 5' untraslated region of PIGF mRNA contains a small open reading frame potentially coding for a peptide of $13 / 15$ amino acids in human and five amino acids in mouse, whose deletion or mutation of potential initiator codons, substantially increase PIGF expression (Maglione et al., 1993b).

\section{Role of PIGF in angiogenesis}

The first evidence of PIGF as pro-angiogenic factor was reported in 1997. Ziche et al. (1997a) demonstrated that PIGF-1 induced a dose-dependent angiogenic response in the rabbit cornea and in the chick embryo chorioallantoic membrane. Subsequently, the generation and the analysis of plgf knock out mouse model have had a central role to unveil the biological functions of PIGF. Despite the high level of expression in placenta, the absence of PIGF did not compromise the normal embryonic development of the mice. Indeed, plgf null mice born at a Mendelian frequency are healthy and fertile (Carmeliet et al., 2001). PIGF is also dispensable for physiological angiogenesis induced in the heart and muscle by exercise (Gigante et al., 2004). This indicates that PIGF is redundant for vascular development and physiological vessel maintenance in healthy adults. However, in the adult, the knock out of plgf impairs angiogenesis and arteriogenesis during pathological conditions such as tumor growth, heart, limb and ocular ischemia, (Carmeliet et al., 2001; Luttun et al., 2002; Pipp et al., 2003; Rakic et al., 2003). Another mouse model, the double knock out for plgf and enodothelial nitric oxide synthase (eNos), has further evidenced the importance of PIGF in pathological angiogenesis. eNOS and its final by-product nitric oxide (NO) represent a downstream target for the angiogenic response elicited by VEGF-A (Papapetropoulos et al., 1997; Ziche et al., 1997b). eNos -/- mice, like plgf -/-, showed a reduced neo-angiogenesis in pathological conditions 
(Murohara et al., 1998). The mouse carrying the combined deletion of the two genes showed, in mild hind limb ischemia model, a heterogeneous ischemic phenotype ranging from cyanosis of finger-tip to self-amputation and increased death rate occurring in $47 \%$ of the animals undergoing the surgical procedure.

This model has represented the first experimental animal model of defective angiogenesis that allows individuating a functional link between PIGF and eNOS (Gigante et al., 2006). These experiments of loss-of-function clearly indicated that the activity of PIGF seems to be confined to the pathological conditions.

The involvement of PIGF in stimulating angiogenesis was also confirmed in gain-of-function studies. Transgenic mice overexpressing plgf in skin under the control of keratin-14 promoter showed a substantial increase in number, branching and size of dermal blood vessels, with a significant increase of mature smooth muscle-coated vessels, together with enhanced vascular leakiness (Odorisio et al., 2002). Accordingly, adenovirus-mediated PIGF transfer in the ischemic heart and limb was able to elicit a strong angiogenic response, giving rise to numerous larger vessels, with an efficacy almost comparable to that of VEGF-A (Luttun et al., 2002). The same approach of delivery in xenograft tumors did not show an increase in terms of tumor volume and vessel density but generated an increase in terms of vessel lumen, inflammatory infiltrate and vessel maturation (Tarallo et al., 2010). Delivery of recombinant PIGF homodimer or PIGF/VEGF-A heterodimer significantly promoted angiogenesis in ischemic conditions (Luttun et al., 2002; Autiero et al., 2003).

Gain and loss of function experiments have clearly indicated that PIGF promotes pathological angiogenesis acting at different levels. Indeed, it may directly stimulate vessel growth by acting on the growth, migration and survival of endothelial cells (Ziche et al., 1997a; Carmeliet et al., 2001; Adini et al., 2002; Fischer et al., 2007) and vessel maturation, by increasing the proliferation and recruitment of smooth-muscle cells and supporting the proliferation of fibroblasts (Yonekura et al., 1999; Bellik et al., 2005). Moreover PIGF is crucial for the recruitment and maturation of bone marrowderived progenitors involved in angiogenic process (Hattori et al., 2002; Rafii et al., 2003) and to promote differentiation and activation of monocyte-macrophage lineage that are able to further support the angiogenic stimulus (Clauss et al., 1996; Scholz et al., 2003; Selvaraj et al., 2003).

The wide spectrum of paracrine action of PIGF is directly correlated to the expression of VEGFR-1 receptor on many cell lineages (Fischer et al., 2008). The specific role of PIGF in pathological conditions was further confirmed by the observation that during pathological angiogenesis cells having a role in this biological phenomenon, like endothelial cells (Yonekura et al., 1999; Ponticelli et al., 2008; Tarallo et al., 2010), smooth muscle cells (Yonekura et al., 1999), fibroblasts (Green et al., 2001), bonemarrow progenitors (Lyden et al., 2001; Hattori et al., 2002), over-express or start to express PIGF. Since these cells also express VEGFR-1 receptor, PIGF exerts also autocrine activity to sustain angiogenesis.

\section{Role of PIGF in different diseases}

The study of PIGF in pathological angiogenesis has allowed to assign to PIGF/VEGFR-1 axis a central role in the activation and sustainment of the inflammatory switch associated with neo-angiogenesis. Furthermore, many other cell types express PIGF in pathological conditions, such as keratinocytes (Odorisio et al., 2006), cardiomyocytes (Luttun et al., 2002), retinal pigment epithelial cells (Hollborn et al., 2006; Miyamoto et al., 2007), bronchial epithelial cells (Mohammed et al., 2007) and tumour cells (Parr et al., 2005; Wei et al., 2005; Fischer et al., 2007). This upregulation is due not only to hypoxia but also to other stimulus including nitric oxide (Mohammed et al., 2007), cytokines, as interleukin 1 and tumour necrosis factor- $\alpha$ (De Ceuninck et al., 2004), growth factors, as transforming growth factor- $\beta 1$ (Yao et al., 2005), and oncogenes (Larcher et al., 2003). VEGFR-1 is positively modulated by hypoxia in pathological conditions (Larcher et al., 2003).

These data have prompted to investigate whether PIGF has a role in other pathologies and once again the plgf knock out mouse has been crucial for these studies. Indeed it has been reported that PIGF plays a role also in atherosclerosis, cutaneous delayed-type hypersensitivity, obesity, cartilage and bone repair and in rheumatoid arthritis (Carmeliet et al., 2001; Oura et al., 2003; Lijnen et al., 2006; Maes et al., 2006; Yoo et al., 2009). In all pathological models studied, the absence of PIGF impaired the associated inflammation and/ or the angiogenesis determining a general reduction of pathological status. In addition, in the model of fracture repair it has been demonstrated that PIGF is able to activate also unexpected mechanisms. It induced proliferation and osteogenic differentiation of mesenchymal progenitors stimulating cartilage turnover as well as the remodeling of the newly formed bone by stimulating osteoclasts differen- 
tiation. As expected, all the cell types involved in these biological processes express VEGFR-1 receptor.

\section{Recent insights}

Two new important functions have been recently described for PIGF. The first concerns the polarization status of tumor-associated macrophages (TAM). In non-progressing or regressing tumors, TAMs present a classic M1-like macrophage activation program, characterized by proinflammatory activity, antigen presentation and tumor lysis. In malignant tumors, TAMs show M2-type activation that determines increased angiogenesis and tumor cell intra/extravasation and growth. In this status they suppress antitumor immunity by preventing activation of dendritic cells, CTLs, and NK cells (Mantovani and Sica, 2010; Qian and Pollard, 2010). Ronly et al. (2011) have reported that host-produced histidine-rich glycoprotein promotes the antitumor immune response and vessel normalization, effects known to decrease tumor growth and metastasis and to enhance chemotherapy, by skewing TAM polarization away from the M2- to M1-like phenotype. This effect was obtained by down-regulation of PIGF. Therefore PIGF is important to sustain the pro- angiogenic M2-type phenotype.

The second concerns the response necessary for adaptive cardiac remodeling during transverse aortic constriction (Carnevale et al., 2011). The cardiac remodeling proceeds by an early adaptive hypertrophic response, characterized by coordinated cardiomyocyte growth, angiogenesis and inflammation (Hunter and Chien, 1999; Frey and Olson, 2003). The absence of PIGF entailed a dysregulation of cardiac remodeling that negatively affects muscle growth, mainly ascribable to a failure in establishment of adequate inflammatory response. At molecular level, an impaired activity of TNF- $\alpha$ converting enzyme (TACE) due to a strong increase of its main natural inhibitor, tissue inhibitor of metalloproteinases (TIMP)-3 has been observed (Vanhoutte and Heymans, 2010). TACE is essential to activate TNF- $\alpha$ from a membranebound form, one of the earliest inflammatory events in overloaded hearts (Wang et al., 2009; Ding et al., 2010). Therefore, PIGF finely tunes a balanced regulation of TIMP-3/TACE axis, allowing the establishment of an inflammatory response necessary for adaptive cardiac remodeling.

\section{Concluding remarks}

PIGF is a multitasking cytokine able to stimulate angiogenesis by direct or indirect mechanisms thanks to its ability to bind and activate VEGFR-1 receptor expressed in many cell types involved in this biological process. Although initially controversial data have been reported on the pro-angiogenic role of PIGF (De Falco et al., 2002; Carmeliet and Jain, 2011), the numerous studies of the last decade undoubtedly support its role in angiogenesis. Furthermore, these studied have clearly evidenced the crucial role of PIGF in modulating the inflammation associated not only to pathological angiogenesis but also to other diseases. These data have strongly stimulated the search for inhibitor of PIGF for therapeutic approaches. Once again controversial data have produced (Bais et al., 2010; Van de Veire et al., 2010), nonetheless a neutralizing anti-PIGF antibody is now in phase two of clinical trials (Martinsson-Niskanen et al., 2011). Considering the therapeutic perspective, the search for a physiological function of endogenous PIGF still continues because the elucidation of its physiological role became crucial to predict the possible adverse affects of PIGF inhibitors.

\section{Acknowledgements}

The author declares no conflict of interests. This work was supported by grants from: AIRC (Associazione Italiana Ricerca sul Cancro, grant number IG 11420), Telethon - Italy (grant number GGP08062), Italian Ministry of Scientific Research (grant MERIT, Medical Research in Italy). The author thanks Anna Maria Aliperti for manuscript editing.

\section{References}

Achen MG, Gad JM, Stacker SA, Wilks AF. Placenta growth factor and vascular endothelial growth factor are co-expressed during early embryonic development. Growth Factors 1997;15:69-80

Adini A, Kornaga T, Firoozbakht F, Benjamin LE. Placental growth factor is a survival factor for tumor endothelial cells and macrophages. Cancer Res 2002;62:2749-52

Arrick BA, Lee AL, Grendell RL, Derynck R. Inhibition of translation of transforming growth factor- $\beta 3$ mRNA by its 5 ' untranslated region. Mol Cell Biol 1991;11:4306-13

Autiero M, Waltenberger J, Communi D, Kranz A, Moons L, Lambrechts D, Kroll J, Plaisance S, De Mol M, Bono F, Kliche S, Fellbrich G, Ballmer-Hofer K, Maglione D, Mayr-Beyrle U, Dewerchin $M$, Dombrowski S, Stanimirovic D, Van Hummelen P, Dehio C, Hicklin DJ, Persico G, Herbert JM, Communi D, Shibuya M, Collen D, Conway EM, Carmeliet P. Role of PIGF in the intra- and intermolecular cross talk between the VEGF receptors Flt1 and Flk1. Nat Med 


\section{3;9:936-43}

Bais C, Wu X, Yao J, Yang S, Crawford Y, McCutcheon K, Tan C, Kolumam G, Vernes JM, Eastham-Anderson J, Haughney P, Kowanetz M, Hagenbeek T, Kasman I, Reslan HB, Ross J, Van Bruggen N, Carano RA, Meng YJ, Hongo JA, Stephan JP, Shibuya M, Ferrara N. PIGF blockade does not inhibit angiogenesis during primary tumor growth. Cell 2010;141: 166-77

Bellik L, Vinci MC, Filippi S, Ledda F, Parenti A. Intracellular pathways triggered by the selective FLT-1- agonist placental growth factor in vascular smooth muscle cells exposed to hypoxia. Br J Pharmacol 2005;146:568-75

Cao Y. Positive and negative modulation of angiogenesis by VEGFR1 ligands. Sci Signal 2009;2:re1

Cao Y, Ji WR, Qi P, Rosin A. Placenta growth factor: identification and characterization of a novel isoform generated by RNA alternative splicing. Biochem Biophys Res Commun 1997;235:493-8

Carmeliet P, Jain RK. Molecular mechanisms and clinical applications of angiogenesis. Nature 2011;473:298-307

Carmeliet P, Moons L, Luttun A, Vincenti V, Compernolle V, De Mol M, Wu Y, Bono F, Devy L, Beck H, Scholz D, Acker T, DiPalma T, Dewerchin M, Noel A, Stalmans I, Barra A, Blacher S, Vandendriessche T, Ponten A, Eriksson U, Plate $\mathrm{KH}$, Foidart JM, Schaper W, Charnock-Jones DS, Hicklin DJ, Herbert JM, Collen D, Persico MG. Synergism between vascular endothelial growth factor and placental growth factor contributes to angiogenesis and plasma extravasation in pathological conditions. Nat Med 2001;7:575-83

Carnevale D, Cifelli G, Mascio G, Madonna M, Sbroggio M, Perrino C, Persico MG, Frati G, Lembo G. Placental growth factor regulates cardiac inflammation through the tissue inhibitor of metalloproteinases-3/tumor necrosis factoralpha-converting enzyme axis: crucial role for adaptive cardiac remodeling during cardiac pressure overload. Circulation 2011;124:1337-50

Christinger HW, Fuh G, de Vos AM, Wiesmann C. The crystal structure of placental growth factor in complex with domain 2 of vascular endothelial growth factor receptor-1. J Biol Chem 2004;279:10382-8

Clauss M, Weich H, Breier G, Knies U, Rockl W, Waltenberger J, Risau W. The vascular endothelial growth factor receptor Flt-1 mediates biological activities. Implications for a functional role of placenta growth factor in monocyte activation and chemotaxis. J Biol Chem 1996;271:17629-34

Cramer M, Nagy I, Murphy BJ, Gassmann M, Hottiger MO, Georgiev O, Schaffner W. NF-kappaB contributes to transcription of placenta growth factor and interacts with metal responsive transcription factor- 1 in hypoxic human cells. Biol Chem 2005;386:865-72

Davis-Smyth T, Presta LG, Ferrara N. Mapping the charged residues in the second immunoglobulin-like domain of the vascular endothelial growth factor/placenta growth factor receptor Flt-1 required for binding and structural stability. $J$ Biol Chem 1998;273:3216-22

De Ceuninck F, Dassencourt L, Anract P. The inflammatory side of human chondrocytes unveiled by antibody microarrays. Biochem Biophys Res Commun 2004;323: 960-9

De Falco S, Gigante B, Persico MG. Structure and function of placental growth factor. Trends Cardiovasc Med 2002;12:241-6

de Vries C, Escobedo JA, Ueno H, Houck K, Ferrara N, Williams LT. The fms-like tyrosine kinase, a receptor for vascular endothelial growth factor. Science 1992;255:989-91

Ding Y, Huang Y, Song N, Gao X, Yuan S, Wang X, Cai H, Fu Y, Luo Y. NFAT1 mediates placental growth factor-induced myelomonocytic cell recruitment via the induction of TNF- $\alpha$. $\mathrm{J}$ Immunol 2010;184:2593-601

DiPalma T, Tucci M, Russo G, Maglione D, Lago CT, Romano A, Saccone S, Della Valle G, De Gregorio L, Dragani TA, Viglietto G, Persico MG. The placenta growth factor gene of the mouse. Mamm Genome 1996;7:6-12

DiSalvo J, Bayne ML, Conn G, Kwok PW, Trivedi PG, Soderman DD, Palisi TM, Sullivan KA, Thomas KA. Purification and characterization of a naturally occurring vascular endothelial growth factor.placenta growth factor heterodimer. J Biol Chem 1995;270:7717-23

Errico M, Riccioni T, lyer S, Pisano C, Acharya KR, Persico $M G$, De Falco $S$. Identification of placenta growth factor determinants for binding and activation of Flt-1 receptor. $J$ Biol Chem 2004;279:43929-39

Ferrara N, Gerber HP, LeCouter J. The biology of VEGF and its receptors. Nat Med 2003;9:669-76

Fischer C, Jonckx B, Mazzone M, Zacchigna S, Loges S, Pattarini L, Chorianopoulos E, Liesenborghs L, Koch M, De Mol M, Autiero M, Wyns S, Plaisance S, Moons L, van Rooijen N, Giacca M, Stassen JM, Dewerchin M, Collen D, Carmeliet P. Anti-PIGF inhibits growth of VEGF(R)- inhibitor-resistant tumors without affecting healthy vessels. Cell 2007;131: 463-75

Fischer C, Mazzone M, Jonckx B, Carmeliet P. FLT1 and its ligands VEGFB and PIGF: drug targets for anti-angiogenic therapy? Nat Rev Cancer 2008;8:942-56

Frey N, Olson EN. Cardiac hypertrophy: the good, the bad, and the ugly. Annu Rev Physiol 2003;65:45-79

Gaur P, Bielenberg DR, Samuel S, Bose D, Zhou Y, Gray MJ, Dallas NA, Fan F, Xia L, Lu J, Ellis LM. Role of class 3 semaphorins and their receptors in tumor growth and angiogenesis. Clin Cancer Res 2009;15:6763-70

Gigante B, Tarsitano M, Cimini V, De Falco S, Persico MG. Placenta growth factor is not required for exercise-induced angiogenesis. Angiogenesis 2004;7:277-84

Gigante B, Morlino G, Gentile MT, Persico MG, De Falco S. Plgf-/-eNos-/- mice show defective angiogenesis associated with increased oxidative stress in response to tissue ischemia. FASEB J 2006;20:970-2

Green CJ, Lichtlen P, Huynh NT, Yanovsky M, Laderoute KR, Schaffner W, Murphy BJ. Placenta growth factor gene expression is induced by hypoxia in fibroblasts: a central role for metal transcription factor-1. Cancer Res 2001;61: 2696-703 
Hattori K, Heissig B, Wu Y, Dias S, Tejada R, Ferris B, Hicklin DJ, Zhu Z, Bohlen P, Witte L, Hendrikx J, Hackett NR, Crystal RG, Moore MA, Werb Z, Lyden D, Rafii S. Placental growth factor reconstitutes hematopoiesis by recruiting VEGFR1(+) stem cells from bone-marrow microenvironment. Nat Med 2002;8:841-9

Hauser S, Weich HA. A heparin-binding form of placenta growth factor (PIGF-2) is expressed in human umbilical vein endothelial cells and in placenta. Growth Factors 1993;9: 259-68

Hollborn M, Tenckhoff S, Seifert M, Kohler S, Wiedemann P, Bringmann A, Kohen L. Human retinal epithelium produces and responds to placenta growth factor. Graefes Arch Clin Exp Ophthalmol 2006;244:732-41

Hunter JJ, Chien KR. Signaling pathways for cardiac hypertrophy and failure. N Engl J Med 1999;341:1276-83

lyer S, Leonidas DD, Swaminathan GJ, Maglione D, Battisti $M$, Tucci M, Persico MG, Acharya KR. The crystal structure of human placenta growth factor-1 (PIGF-1), an angiogenic protein, at 2.0 A resolution. J Biol Chem 2001;276:12153-61

Iyer S, Darley PI, Acharya KR. Structural insights into the binding of vascular endothelial growth factor-B by VEGFR-1(D2): recognition and specificity. J Biol Chem 2010;285:23779-89

Kelly BD, Hackett SF, Hirota K, Oshima Y, Cai Z, Berg-Dixon S, Rowan A, Yan Z, Campochiaro PA, Semenza GL. Cell type-specific regulation of angiogenic growth factor gene expression and induction of angiogenesis in nonischemic tissue by a constitutively active form of hypoxia-inducible factor 1. Circ Res 2003;93:1074-81

Keyt BA, Nguyen HV, Berleau LT, Duarte CM, Park J, Chen $\mathrm{H}$, Ferrara $\mathrm{N}$. Identification of vascular endothelial growth factor determinants for binding KDR and FLT-1 receptors. Generation of receptor-selective VEGF variants by site-directed mutagenesis. J Biol Chem 1996;271:5638-46

Khaliq A, Li XF, Shams M, Sisi P, Acevedo CA, Whittle MJ, Weich $\mathrm{H}$, Ahmed A. Localisation of placenta growth factor (PIGF) in human term placenta. Growth Factors 1996; 13:243-50, color plates I-II,pre bk cov

Kozak M. An analysis of 5'-noncoding sequences from 699 vertebrate messenger RNAs. Nucleic Acids Res 1987;15: 8125-48

Larcher F, Franco M, Bolontrade M, Rodriguez-Puebla M, Casanova L, Navarro M, Yancopoulos G, Jorcano JL, Conti CJ. Modulation of the angiogenesis response through Ha-ras control, placenta growth factor, and angiopoietin expression in mouse skin carcinogenesis. Mol Carcinog 2003;37:83-90

Lijnen HR, Christiaens V, Scroyen I, Voros G, Tjwa M, Carmeliet $P$, Collen D. Impaired adipose tissue development in mice with inactivation of placental growth factor function. Diabetes 2006;55:2698-704

Luttun A, Tjwa M, Moons L, Wu Y, Angelillo-Scherrer A, Liao F, Nagy JA, Hooper A, Priller J, De Klerck B, Compernolle V, Daci E, Bohlen P, Dewerchin M, Herbert JM, Fava R, Matthys P, Carmeliet G, Collen D, Dvorak HF, Hicklin DJ, Carmeliet P. Revascularization of ischemic tissues by PIGF treatment, and inhibition of tumor angiogenesis, arthritis and atherosclerosis by anti-FIt1. Nat Med 2002;8:831-40

Lyden D, Halakrishnan R, Moermans K, Smets N, Verfaillie CM, Caattori K, Dias S, Costa C, Blaikie P, Butros L, Chadburn A, Heissig B, Marks W, Witte L, Wu Y, Hicklin D, Zhu Z, Hackett NR, Crystal RG, Moore MA, Hajjar KA, Manova K, Benezra R, Rafii S. Impaired recruitment of bone-marrow-derived endothelial and hematopoietic precursor cells blocks tumor angiogenesis and growth. Nat Med 2001;7:1194-201

Maes C, Coenegrachts L, Stockmans I, Daci E, Luttun A, Petryk A, Goprmeliet P, Bouillon R, Carmeliet G. Placental growth factor mediates mesenchymal cell development, cartilage turnover, and bone remodeling during fracture repair. J Clin Invest 2006;116:1230-42

Maglione D, Guerriero V, Viglietto G, Delli-Bovi P, Persico MG. Isolation of a human placenta cDNA coding for a protein related to the vascular permeability factor. Proc Natl Acad Sci USA 1991;88:9267-71

Maglione D, Guerriero V, Viglietto G, Ferraro MG, Aprelikova O, Alitalo K, Del Vecchio S, Lei KJ, Chou JY, Persico MG. Two alternative mRNAs coding for the angiogenic factor, placenta growth factor (PIGF), are transcribed from a single gene of chromosome 14. Oncogene 1993a;8:925-31

Maglione D, Guerriero V, Rambaldi M, Russo G, Persico MG. Translation of the placenta growth factor mRNA is severely affected by a small open reading frame localized in the $5^{\prime}$ untranslated region. Growth Factors 1993b;8:141-52

Mamluk R, Gechtman Z, Kutcher ME, Gasiunas N, Gallagher J, Klagsbrun M. Neuropilin-1 binds vascular endothelial growth factor 165 , placenta growth factor-2, and heparin via its b1b2 domain. J Biol Chem 2002;277:24818-25

Mantovani A, Sica A. Macrophages, innate immunity and cancer: balance, tolerance, and diversity. Curr Opin Immunol 2010;22:231-7

Martinsson-Niskanen T, Riisbro R, Larsson L, Winstedt L, Stenberg Y, Pakola S, Stassen JM, Glazer S. Monoclonal antibody TB-403: a first-in-human, Phase I, double-blind, dose escalation study directed against placental growth factor in healthy male subjects. Clin Ther 2011;33:1142-9

Migdal M, Huppertz B, Tessler S, Comforti A, Shibuya M, Reich R, Baumann H, Neufeld G. Neuropilin-1 is a placenta growth factor-2 receptor. J Biol Chem 1998;273:22272-8

Miyamoto N, de Kozak Y, Jeanny JC, Glotin A, Mascarelli F, Massin P, BenEzra D, Behar-Cohen F. Placental growth factor-1 and epithelial haemato-retinal barrier breakdown: potential implication in the pathogenesis of diabetic retinopathy. Diabetologia 2007;50:461-70

Mohammed KA, Nasreen N, Tepper RS, Antony VB. Cyclic stretch induces PIGF expression in bronchial airway epithelial cells via nitric oxide release. Am J Physiol Lung Cell Mol Physiol 2007;292:L559-66

Muller AJ, Witte ON. The 5 ' noncoding region of the human leukemia-associated oncogene BCR/ABL is a potent inhibitor of in vitro translation. Mol Cell Biol 1989;9:5234-8

Muller YA, Christinger HW, Keyt BA, de Vos AM. The crystal 
structure of vascular endothelial growth factor (VEGF) refined to $1.93 \mathrm{~A}$ resolution: multiple copy flexibility and receptor binding. Structure 1997;5:1325-38

Murohara T, Asahara T, Silver M, Bauters C, Masuda H, Kalka C, Kearney M, Chen D, Symes JF, Fishman MC, Huang PL, Isner JM. Nitric oxide synthase modulates angiogenesis in response to tissue ischemia. J Clin Invest 1998;101: 2567-78

Odorisio T, Schietroma C, Zaccaria ML, Cianfarani F, Tiveron C, Tatangelo L, Failla CM, Zambruno G. Mice overexpressing placenta growth factor exhibit increased vascularization and vessel permeability. J Cell Sci 2002;115: 2559-67

Odorisio T, Cianfarani F, Failla CM, Zambruno G. The placenta growth factor in skin angiogenesis. J Dermatol Sci 2006;41:11-9

Olofsson B, Korpelainen E, Pepper MS, Mandriota SJ, Aase K, Kumar V, Gunji Y, Jeltsch MM, Shibuya M, Alitalo K, Eriksson U. Vascular endothelial growth factor B (VEGF-B) binds to VEGF receptor-1 and regulates plasminogen activator activity in endothelial cells. Proc Natl Acad Sci USA 1998;95:11709-14

Oura H, Bertoncini J, Velasco P, Brown LF, Carmeliet P, Detmar M. A critical role of placental growth factor in the induction of inflammation and edema formation. Blood 2003;101:560-7

Papapetropoulos A, Garcia-Cardena G, Madri JA, Sessa WC. Nitric oxide production contributes to the angiogenic properties of vascular endothelial growth factor in human endothelial cells. J Clin Invest 1997;100:3131-9

Park JE, Chen HH, Winer J, Houck KA, Ferrara N. Placenta growth factor. Potentiation of vascular endothelial growth factor bioactivity, in vitro and in vivo, and high affinity binding to Flt-1 but not to Flk-1/KDR. J Biol Chem 1994;269: 25646-54

Parkin N, Darveau A, Nicholson R, Sonenberg N. cis-acting translational effects of the 5 ' noncoding region of c-myc mRNA. Mol Cell Biol 1988;8:2875-83

Parr C, Watkins G, Boulton M, Cai J, Jiang WG. Placenta growth factor is over-expressed and has prognostic value in human breast cancer. Eur J Cancer 2005;41:2819-27

Persico MG, Vincenti V, DiPalma T. Structure, expression and receptor-binding properties of placenta growth factor (PIGF). Curr Top Microbiol Immunol 1999;237:31-40

Pipp F, Heil M, Issbrucker K, Ziegelhoeffer T, Martin S, van den Heuvel J, Weich H, Fernandez B, Golomb G, Carmeliet $P$, Schaper W, Clauss M. VEGFR-1-selective VEGF homologue PIGF is arteriogenic: evidence for a monocytemediated mechanism. Circ Res 2003;92:378-85

Ponticelli S, Marasco D, Tarallo V, Albuquerque RJ, Mitola S, Takeda A, Stassen JM, Presta M, Ambati J, Ruvo M, De Falco $S$. Modulation of angiogenesis by a tetrameric tripeptide that antagonizes vascular endothelial growth factor receptor $1 . \mathrm{J}$ Biol Chem 2008;283:34250-9

Qian BZ, Pollard JW. Macrophage diversity enhances tumor progression and metastasis. Cell 2010;141:39-51

Rafii S, Avecilla S, Shmelkov S, Shido K, Tejada R, Moore
MA, Heissig B, Hattori K. Angiogenic factors reconstitute hematopoiesis by recruiting stem cells from bone marrow microenvironment. Ann N Y Acad Sci 2003;996:49-60

Rakic JM, Lambert V, Devy L, Luttun A, Carmeliet P, Claes C, Nguyen L, Foidart JM, Noel A, Munaut C. Placental growth factor, a member of the VEGF family, contributes to the development of choroidal neovascularization. Invest Ophthalmol Vis Sci 2003;44:3186-93

Rolny C, Mazzone M, Tugues S, Laoui D, Johansson I, Coulon C, Squadrito ML, Segura I, Li X, Knevels E, Costa S, Vinckier S, Dresselaer T, Akerud P, De Mol M, Salomaki H, Phillipson M, Wyns S, Larsson E, Buysschaert I, Botling J, Himmelreich U, Van Ginderachter JA, De Palma M, Dewerchin M, Claesson-Welsh L, Carmeliet P. HRG inhibits tumor growth and metastasis by inducing macrophage polarization and vessel normalization through downregulation of PIGF. Cancer Cell 2011;19:31-44

Scholz D, Elsaesser H, Sauer A, Friedrich C, Luttun A, Carmeliet $P$, Schaper W. Bone marrow transplantation abolishes inhibition of arteriogenesis in placenta growth factor (PIGF) -/- mice. J Mol Cell Cardiol 2003;35:177-84

Selvaraj SK, Giri RK, Perelman N, Johnson C, Malik P, Kalra VK. Mechanism of monocyte activation and expression of proinflammatory cytochemokines by placenta growth factor. Blood 2003;102:1515-24

Semenza GL. Regulation of mammalian $\mathrm{O} 2$ homeostasis by hypoxia-inducible factor 1 . Annu Rev Cell Dev Biol 1999; 15:551-78

Takahashi $\mathrm{H}$, Shibuya M. The vascular endothelial growth factor (VEGF)/VEGF receptor system and its role under physiological and pathological conditions. Clin Sci (Lond) 2005;109:227-41

Tarallo V, Vesci L, Capasso O, Esposito MT, Riccioni T, Pastore L, Orlandi A, Pisano C, De Falco S. A placental growth factor variant unable to recognize vascular endothelial growth factor (VEGF) receptor-1 inhibits VEGFdependent tumor angiogenesis via heterodimerization. Cancer Res 2010;70:1804-13

Terman BI, Dougher-Vermazen M, Carrion ME, Dimitrov D, Armellino DC, Gospodarowicz D, Bohlen P. Identification of the KDR tyrosine kinase as a receptor for vascular endothelial cell growth factor. Biochem Biophys Res Commun 1992;187:1579-86

Van de Veire S, Stalmans I, Heindryckx F, Oura H, TijerasRaballand A, Schmidt T, Loges S, Albrecht I, Jonckx B, Vinckier S, Van Steenkiste C, Tugues S, Rolny C, De Mol M, Dettori D, Hainaud P, Coenegrachts L, Contreres JO, Van Bergen T, Cuervo H, Xiao WH, Le Henaff C, Buysschaert I, Kharabi Masouleh B, Geerts A, Schomber T, Bonnin P, Lambert V, Haustraete J, Zacchigna S, Rakic JM, Jimenez W, Noel A, Giacca M, Colle I, Foidart JM, Tobelem G, Morales-Ruiz M, Vilar J, Maxwell P, Vinores SA, Carmeliet G, Dewerchin M, Claesson-Welsh L, Dupuy E, Van Vlierberghe H, Christofori G, Mazzone M, Detmar M, Collen $D$, Carmeliet P. Further pharmacological and genetic evidence for the efficacy of PIGF inhibition in cancer and eye disease. Cell 2010;141:178-90

Vanhoutte D, Heymans S. TIMPs and cardiac remodeling: 
'Embracing the MMP-independent-side of the family'. J Mol Cell Cardiol 2010;48:445-53

Viglietto G, Maglione D, Rambaldi M, Cerutti J, Romano A, Trapasso F, Fedele M, Ippolito P, Chiappetta G, Botti G, et al. Upregulation of vascular endothelial growth factor (VEGF) and downregulation of placenta growth factor (PIGF) associated with malignancy in human thyroid tumors and cell lines. Oncogene 1995;11:1569-79

Voros G, Maquoi E, Demeulemeester D, Clerx N, Collen D, Lijnen HR. Modulation of angiogenesis during adipose tissue development in murine models of obesity. Endocrinology 2005;146:4545-54

Vuorela P, Hatva E, Lymboussaki A, Kaipainen A, Joukov V, Persico MG, Alitalo K, Halmesmaki E. Expression of vascular endothelial growth factor and placenta growth factor in human placenta. Biol Reprod 1997;56:489-94

Wang X, Oka T, Chow FL, Cooper SB, Odenbach J, Lopaschuk GD, Kassiri Z, Fernandez-Patron C. Tumor necrosis factor- $\alpha$-converting enzyme is a key regulator of agonist-induced cardiac hypertrophy and fibrosis. Hypertension 2009;54:575-82

Wei SC, Tsao PN, Yu SC, Shun CT, Tsai-Wu JJ, Wu CH, Su YN, Hsieh FJ, Wong JM. Placenta growth factor expression is correlated with survival of patients with colorectal cancer. Gut 2005;54:666-72

Wiesmann C, Fuh G, Christinger HW, Eigenbrot C, Wells JA, de Vos AM. Crystal structure at 1.7 A resolution of VEGF in complex with domain 2 of the Flt-1 receptor. Cell 1997;91:695-704

Yamakawa M, Liu LX, Date T, Belanger AJ, Vincent KA, Akita GY, Kuriyama T, Cheng SH, Gregory RJ, Jiang C. Hypoxia-inducible factor- 1 mediates activation of cultured vascular endothelial cells by inducing multiple angiogenic factors. Circ Res 2003:93:664-73

Yang W, Ahn H, Hinrichs M, Torry RJ, Torry DS. Evidence of a novel isoform of placenta growth factor (PIGF-4) expressed in human trophoblast and endothelial cells. J Reprod Immunol 2003;60:53-60

Yao YG, Yang HS, Cao Z, Danielsson J, Duh EJ. Upregulation of placental growth factor by vascular endothelial growth factor via a post-transcriptional mechanism. FEBS Lett 2005;579:1227-34

Yonekura $\mathrm{H}$, Sakurai S, Liu X, Migita H, Wang H, Yamagishi $\mathrm{S}$, Nomura M, Abedin MJ, Unoki H, Yamamoto Y, Yamamoto $\mathrm{H}$. Placenta growth factor and vascular endothelial growth factor $B$ and $C$ expression in microvascular endothelial cells and pericytes. Implication in autocrine and paracrine regulation of angiogenesis. J Biol Chem 1999;274:35172-8

Yoo SA, Yoon HJ, Kim HS, Chae CB, De Falco S, Cho CS, Kim WU. Role of placenta growth factor and its receptor flt-1 in rheumatoid inflammation: a link between angiogenesis and inflammation. Arthritis Rheum 2009;60:345-54

Zhang H, Palmer R, Gao X, Kreidberg J, Gerald W, Hsiao L, Jensen RV, Gullans SR, Haber DA. Transcriptional activation of placental growth factor by the forkhead/winged helix transcription factor FoxD1. Curr Biol 2003;13:1625-9

Ziche M, Maglione D, Ribatti D, Morbidelli L, Lago CT, Battisti M, Paoletti I, Barra A, Tucci M, Parise G, Vincenti V, Granger HJ, Viglietto G, Persico MG. Placenta growth factor-1 is chemotactic, mitogenic, and angiogenic. Lab Invest 1997a; 76:517-31

Ziche M, Morbidelli L, Choudhuri R, Zhang HT, Donnini S, Granger HJ, Bicknell R. Nitric oxide synthase lies downstream from vascular endothelial growth factorinduced but not basic fibroblast growth factor-induced angiogenesis. J Clin Invest 1997b;99:2625-34 